\title{
IMPLEMENTASI MODEL PEMBELAJARAN INTERAKTIF SETING KOOPERATIF UNTUK MENINGKATKAN MOTIVASI DAN HASIL BELAJAR SISWA KELAS VIII PADA MATA PELAJARAN IPS DI SMP NEGERI 3 PALIMANAN KABUPATEN CIREBON
}

\author{
Nur' ${ }^{1}$, Mahdi ${ }^{2}$ \\ IAIN Syekh Nurjati Cirebon ${ }^{1,2}$ \\ nurnuy837@gmail.com;mahdidrs@icloud.com
}

\begin{abstract}
Abstrak
Salah satu keberhasilan belajar, dipengaruhi oleh metode yang digunakan guru dalam proses pembelajaran, penelitian awal yang dilakukan oleh peneliti di SMP Negeri 3 Palimanan Kabupaten Cirebon yaitu ditemukannya guru yang lebih dominasi menggunakan metode ceramah yang berdampak pada siswa kurang termotivasi dan mendapatkan hasil belajar yang kurang atau di bawah KKM yaitu 75, sedangkan rata-rata kelas baru mencapai 58,03. Maka peneliti terdorong melakukan penelitian untuk meningkatkan motivasi dan hasil belajar siswa dengan menggunakan model Pembelajaran Interaktif Seting Kooperatif. Tujuan umum penelitian tindakan kelas ini adalah untuk meningkatkan motivasi dan hasil belajar siswa dalam pembelajaran IPS, sedangkan tujuan khusus dari penelitian ini adalah untuk mengetahui pelaksanaan pembelajaran menggunakan model Pembelajaran Interaktif Seting Kooperatif, motivasi dan hasil belajar siswa kelas VIII di SMP Negeri 3 Palimanan Kabupaten Cirebon. Penelitian ini menggunakan pendekatan Penelitian Tindakan Kelas (PTK) yang dilaksanakan dengan empat tahapan yaitu penelitian, pelaksanaan, tindakan, observasi, refleksi. Teknik pengumpulan data pada penelitian ini menggunakan observasi, wawancara, tes dan dokumentasi. Hasil implemnetasi model Pembelajaran Interaktif Seting Kooperatif yaitu pada siklus I sebesar 62,5\% siklus II sebesar 92,5\% dan siklus III sebesar 95\%. Peningkatan motivasi belajar siswa siklus I sebesar 57,5\% siklus II sebesar 90\% dan siklus III sebesar 97,5\%, sedangkan hasil belajarnya yaitu pra siklus sebesar 58,03 dengan ketuntasan $14,28 \%$ siklus I sebesar 67 dengan ketuntasan 50\% siklus II sebesar 74 dengan ketuntasan 65\% dan siklus III 80 dengan ketuntasan 85\% dengan demikian dapat disimpulkan bahwasannya implementasi model Pembelajaran Interaktif Seting Kooperatif dapat meningkatkan motivasi dan hasil belajar siswa kelas VIII di SMP Negeri 3 Palimanan Kabupaten Cirebon.
\end{abstract}

Kata Kunci: Pembelajaran, Interaktif Seting Kooperatif, Motivasi, Hasil Belajar 


\begin{abstract}
One of the successes of learning, influenced by the methods used by teachers in the learning process, the initial research conducted by researchers at SMP Negeri 3 Palimanan Regency of Cirebon that the discovery of teachers who are more dominant using lecture methods that impact on students less motivated and get less or below learning outcomes KKM is 75, while the average new class reaches 58.03. So researchers are encouraged to conduct research to improve student motivation and learning outcomes by using the model of Interactive Learning Cooperative Setting. The general objective of this classroom action research is to improve the students' motivation and learning outcomes in IPS learning, while the specific purpose of this research is to know the implementation of learning using the Interactive Learning Model of Cooperative Setting, the motivation and the learning outcomes of the VIII students in SMP Negeri 3 Palimanan Regency of Cirebon. This study uses Classroom Action Research approach (PTK) which is implemented with four stages: research, implementation, action, observation, reflection. Data collection techniques in this study using observation, interviews, tests and documentation. Results of implementation of Interactive Cooperative Learning Model of Co-operative Setting is on the first cycle of $62.5 \%$ cycle II of $92.5 \%$ and III cycle of $95 \%$. Increased student's motivation for the first cycle of $57.5 \%$ cycle II $90 \%$ and the third cycle of $97.5 \%$, while the learning result is pre-cycle of 58.03 with the completeness $14.28 \%$ cycle I of 67 with 50\% completeness cycle II of 74 with the completeness of $65 \%$ and cycle III 80 with $85 \%$ completeness thereby can be concluded that the implementation of the model of Interactive Learning Cooperative Setting can improve the motivation and learning outcomes of students of grade VIII in SMP Negeri 3 Palimanan Regency of Cirebon.
\end{abstract}

Keywords: Cooperative, Learning Model Cooperative Setting, Motivation, Learning Outcomes

\title{
A. PENDAHULUAN
}

\section{Latar Belakang Masalah}

Undang-Undang Nomor 20 Tahun 2003 tentang Sistem Pendidikan Nasional Pasal 3, Tujuan pendidikan nasional adalah mengembangkan potensi peserta didik agar menjadi manusia yang beriman dan bertakwa kepada Tuhan Yang Maha Esa, berakhlak mulia, sehat, berilmu, cakap, kreatif, mandiri, dan menjadi warga negara yang demokratis serta bertanggung jawab (Aryani, 2010: 5).

Kegiatan pembelajaran dilakukan oleh dua orang pelaku, yaitu guru Kegiatan pembelajaran, dalam implementasinya 
mengenal banyak istilah untuk menggambarkan cara mengajar yang akan dilakukan oleh guru. Saat ini, begitu banyak macam strategi ataupun metode pembelajaran yang bertujuan untuk meningkatkan kualitas pembelajaran menjadi lebih baik. Istilah model, pendekatan, strategi, metode, teknik, dan taktik sangat familiar dalam dunia pembelajaran kita, namun terkadang istilah-istilah tersebut membuat bingung para pendidik (Rusman, 2012 : 131).

Motivasi dan hasil belajar sangat berkaitan, biasanya dimana motivasi belajar siswa tinggi, maka akan mendapatkan hasil belajar yang tinggi pula (baik). Kesulitan yang sering ditemukan pada mata pelajaran IPS yaitu dari siswanya yang sangat kurang dalam minat membaca atau kurangnya motivasi belajar siswa sehingga berpengaruh terhadap hasil belajar siswa. Alhasil banyak siswa yang kurang memenuhi KKM (Kriteria Ketuntasan Minimum). KKM yang ditentukan yaitu 75 sedangkan rata-rata kelas hanya sekitar 58.03 dan yang memenuhi KKM dipastikan hanya 30\% atau sekitar 4 siswa selebihnya 70\% belum memenuhi KKM.

Rendahnya motivasi dan hasil belajar siswa dapat disebabkan oleh model atau metode pembelajaran yang diterapkan, karen amodel atau metode pembelajaran yang diterapkan adalah ceramah. Guruhanya membacakan materi yang ada dibuku saja. Sehingga mengakibatkan pembelajaran menjadi pasif.

Salah satu model pembelajaran yang dapat mengatasi masalah motivasi belajar siswa dan rendahnya hasil belajar siswa model Pembelajaran Interaktif Seting Kooperatif. Apabila siswa sudah mempunyai motivasi yang tinggi dalam belajar maka hasil belajar pun akan memuaskan sehingga dapat membantu terealisasikannya tujuan pendidikan di Indonesia. Berdasarkan hal tersebut, peneliti termotivasi untuk mengimplementasikan model Pembelajaran Interaktif Seting Kooperatif untuk meningkatkan motivasi dan hasil belajar siswa kelas VIII SMP Negeri 3 Palimanan Kabupaten Cirebon. 


\section{Rumusan Masalah}

Berdasarkan hasil tersebut, maka permasalahan dalam penelitian ini dapat dirumuskan sebagai berikut :

a. Bagaimana implementasi model pembelajaran interaktif seting kooperatif pada mata pelajaran IPS kelas VIII H di SMP Negeri 3 Palimanan Kabupaten Cirebon?

b. Bagaimana peningkatan motivasi belajar siswa pada mata pelajaran IPS kelas VIII H di SMP Negeri 3 Palimanan Kabupaten Cirebon?

c. Bagaimana peningkatan hasil belajar siswa setelah menggunakan model pembelajaran interaktif seting kooperatif pada mata pelajaran IPS kelas VIII H di SMP Negeri 3 Palimanan Kabupaten Cirebon?

\section{Tujuan Penelitian}

Sejalan dengan rumusan masalah di atas, maka tujuan penelitian ini adalah sebagai berikut:

a. Untuk mengetahui implementasi model pembelajaran interaktif seting kooperatif pada maata pelajaran IPS kelas VIII H di SMP Negeri 3 Palimanan.

b. Untuk mengetahui peningkatan motivasi belajar siswa pada mata pelajaran IPS kelas VIII H di SMP Negeri 3 Palimanan.

c. Untuk mengetahui peningakatan hasil belajar siswa setelah menggunakan model pembelajaran interaktif seting kooperatif pada mata pelajaran IPS kelas VIII H di SMP Negeri 3 Palimanan.

\section{B. KAJIAN TEORI}

\section{Pengertian Metode Pembelajaran Interaktif Setting Kooperatif}

Model PembelajaranInteraktif Seting Kooperatif adalah suatu pendekatan belajar yang merujuk pada pandangan kontruktivisme. Pada model ini menempatkan tim dalam kooperatif antar satu dengan yang lain, dengan kata lain satu kelompok bekerja sama. Di dalam kelompok tiap siswa diberi kesempatan untuk memahami suatu materi yang sudah dijelaskan. 
Airasian dan Walsch (Ratumanan, 2003 : 25) mengemukakan bahwa: Konstruktivisme merupakan penjelasan filsafat tentang sifat dasar pengetahuan. Ini merupakan suatu teori tentang bagaimana siswa belajar. Konstruktivisme didasarkan pada asumsi bahwa orang menciptakan pengetahuan sebagai hasil dari interaksi diantara pengetahuan dan keyakinan yang ada dengan pengetahuan baru.

\section{Pengertian Motivasi Belajar Siswa}

Sadirman (2006: 75) menjelaskan bahwa motivasi belajar adalah keseluruhan daya penggerak di dalam diri siswa yang menimbulkan, menjamin kelangsungan, memberikan arah pada kegiatan belajar sehingga tujuan belajardapat tercapai.

Suprijono (2009: 163) juga mengungkapkan bahwa motivasi belajar adalah proses yang memberi semangat belajar, arah dan kegigihan perilaku yang termotivasi adalah perilaku yang penuh energi, terarah dan bertahan lama. Dimyati dan Mudjiono (2009: 80) yang menyatakan bahwa motivasi belajar merupakan kekuatan mental yang menjadi penggerak siswa untuk belajar.

Berdasarkan pendapat para ahli diatas, dapat disimpulkan bahwa motivasi adalah daya penggerak psikis dalam diri seseorang untuk melakukan kegiatan pembelajaran. Dengan motivasi, seorang siswa akan mampu berhasil dalam kegiatan pembelajarannya karena sudah terdapat dorongan dalam diri siswa tersebut untuk terus semangat dalam melakukan kegiatan pembelajaran.

\section{Pengertian Hasil Belajar Siswa}

Menurut Nasution (1982: 25), keberhasilan belajar adalah suatu perubahan yang terjadi pada individu yang belajar, bukan saja perubahan mengenai pengetahuan, tetapi juga pengetahuan untuk membentuk kecakapan, kebiasaan sikap, pengertian, penguasaan, dan penghargaan dalam diri individu yang belajar.

hasil belajar dapat dilihat dari perubahan yang terjadi pada aspek pengetahuan (semakin tahu/faham/matang), nilai (semakin 
sadar/peka/dewasa), sikap (semakin baik, semakin benar) dan ketrampilan (semakin profesional) yang terjadi pada diri individu (Subur, 2015:12).

\section{Pengertian Mata Pelajaran IPS}

Pendidikan Ilmu Pengetahuan Sosial (IPS) merupakan mata pelajaran atau bidang kajian yang menduduki konsep dasar ilmu sosial yang disusun melalui pendekatan pendidikan dan pertimbangan psikologis, serta kebermaknaannya bagi siswa dalam kehidupannya mulai dari tingkat SD sampai SMA, atau membekali dan mempersiapkan peserta didik untuk melanjutkan pendidikan yang lebih tinggi, khususnya dalam bidang ilmu sosial di Perguruan Tinggi.

\section{Kajian Penelitian Relevan}

Penelitian yang dilakukan oleh Gusti Indra Setiana (2012) dengan judul “Bayu Widiyanto (NIM 080210204318) Jurusan Ilmu Penerapan Model Pembelajaran Interaktif Seting Koopeatif Dengan Media Miniatur untuk Peningkatkan Hasil Belajar IPA pada Siswa Kelas III SDN Kemuning Lor 02”.

a. Persamaan

Penelitian yang dilakukan Bayu Widiyanto sama-sama mengunakan model Pembelajaran Interaktif Seting Koopeatifdengan Media Miniatur dan sama-sama meningkatkan hasil belajar siswa.

b. Perbedaan

Perbedaanya terletak pada mata pelajaran, pada variabel yang diteliti, siklus yang digunakan dan tempat penelitian.

\section{METODE PENELITIAN}

\section{Jenis Penelitian}

Jenis penelitian ini adalah penelitian tindakan kelas (PTK) atau classroom Action Research (CAR). Arikunto (2015: 4) menyatakan PTK merupakan penelitian yang memaparkan terjadinya sebab-akibat dari perlakukan, sekaligus memaparkan apa saja yang terjadi ketika perlakuan diberikan, dan memaparkanseluruh proses sejak awal pemberian perlakuan 
sampai dengan dampak dari perlakuan yang diberikan kepada subjek tindakan.

\section{Desain Penelitian}

Dalam pelaksanaan, penelitian ini menggunakan model Kemmis dan Mc Taggart. Prosedur penelitian tindakan kelas yang digunakan oleh model Kemmis dan Mc Taggart terdiri atas 4 tahap kegiatan, yaitu tahap perencaan (plan). Pelaksanaan (action), pengamatan (observation), dan refleksi (reflection) (Samsu Somadoyo, 2013: 40).

\section{Lokasi dan Waktu Penelitian}

Penelitian tindakan kelas ini dilakukan di kelas VIII H SMP Negeri 3 Palimanan yang terletak di Jl. Dr. Setiabudi Lungbenda Kecamatan Palimanan Kabupaten Cirebon Provinsi Jawa Barat. Penelitian ini dilakukan pada semester genap tahun pelajaran 2017/2018. Pelaksanaan penelitian dilakukan dari minggu ke-3 sampai dengan minggu ke-2 bulan Februari 2018.

\section{Teknik Pengumpulan Data}

Dalam tenik pengumpulan data penelitian menggunakan beberapa teknik antara lain teknik observasi, dokumentasi dan tes.

\section{Instrument Penelitian}

Instrument pengumpulan data merupakan alat yang digunakan dalam sebuah penelitian untuk mengambil data yang dibutuhkan dan sebagai penunjang dalam melakukan teknik pengumpulan data.Dalam penelitian ini menggunakan instrument pengumpulan data berupa tes, lembar observasi, dan pedoman wawancara.

a. Tes berupa pertayaan mengunakan instumen soal berupa pilihan ganda untuk mengukur hasil belajar yang dilakukan setiap akhir pembelajaran.

b. Lembar observasi berupa lembar pengmatan yang terdiri lembar pengamatan aktivitas siswa dan guru saat pembelajaran berlangsung.

c. Pedoman wawancara digunakan untuk mengetahui pendapat siswa dan guru mengenai implementasi model pembelajaran interaktif seting kooperatif. 


\section{Analisis Data}

Analisis data merupakan tahap menganalsis data yang telah diperoleh dalam sebuah tindakan dalm penelitian tindakan kelas.Analisis terdiri dari dua jenis data yaitu data kuantitatif dan data kualitatif.

\section{a. Data Kuantitatif}

Data kuantitatif adalah data berupa angka-angka yang terdapatdi dalam sebuah tindakan penelitian yang dianalisis secara statistik.Dalam penelitian ini data kuantitatifakan diperoleh dari tes, angket, lembar pengamatn siswa. Data ini akan dianalsis menggunakan analisis statistic deskriptif dengan menganalisis tes setiap siklus.

1) Untuk menentukan nilai akhir belajar individu

$N A=\frac{\sum x}{M} \times 100$

Keterangan:

NA = Nilai Akhir

$\sum \mathrm{x}=$ Jumlah keseluruhan skor yang diperoleh

M = Jumlah keseluruhan skor maksimal (Djamarah, 2005: 331)

2) Untuk menentukan nilai rata-rata kelas

$\bar{X}=\frac{\sum N A}{M}$

Keterangan:

$\bar{X}=$ rata-rata kelas

$\sum N_{A}=$ Jumlah Nilai Akhir Siswa

N = Jumlah Siswa (Sudjana, 2016: 109)

3) Untuk menghitung presentase ketuntasan belajar siswa

$P=\frac{F}{N} \times 100 \%$

Keterangan:

$\mathrm{P}=$ Persentase

$\mathrm{F}=$ Jumlah siswa yang tuntas belajar

$\mathrm{N}=$ Jumlah seluruh siswa (Djamarah, 2005: 264) 


\section{b. Data Kualitatif}

Data kualitatif adalah adalah data yang berupa informasi berbentuk kalimat yang memberi gambaran tentang ekpresi siswa berkaitan dengan tingkat pemahaman terhadap suatu mata pelajaran (kognitif), pandangan atau sikap siswa terhadap metode atau ajaran yang baru (afektif), aktivitas siswa mengikuti pelajaran, perhatian, antusias dalam belajar, kepercayaan diri, motivasi belajar dan yang dapat dianalsisi secara kualitatif (Kunandar, 2013: 128). Dalam penelitian ini data kualitatif diperoleh dari studi dokumentasi dan hasil wawancara.

\section{HASIL PENELITIAN DAN PEMBAHASAN}

Penelitian ini menggunakan model dari Kemis dan Mc Taggart. Prosedur penelitan tindakan kelas yang digunakan oleh Kemis dan Mc Taggart terdiri dari empat tahap kegiatan, yaitu tahap perencanaan (plan), pelaksanaan tindakan (action), pengamatan (observation, dan refleksi (reflection).Model Kemmis \& Taggart merupakan pengembangan dari konsep dasar yang diperkenalkan Kurt lewin seperti yang diuraikan di atas, hanya saja komponen acting dan observing dijadikan satu kesatuan karena keduanya merupakan tindakan yang tidak terpisahkan, terjadi dalam waktu yang sama. (Syaodih, 2010: 140).

Hasil data tersebut menunjukan bahwa implementasi model Pembelajaran Interaktif Seting Kooperatif mengalami peningkatan motivasi belajar dan hasil belajar siswa kelas VIII H SMP Negeri 3 Palimanan Kabupaten Cirebon.

Leikin dan Zaslavsky (Ratunaman, 2000 : 3) mengemukakan bahwa pembelajaran interaktif setting kooperaitf adalah memungkinkan guru dan siswa untuk saling mempengaruhi berpikir masing-masing. Guru membuat tugas yang memancing siswa berpikir, siswa membangun aturan-aturan dan belajar strategi belajar. Pola interaksi optimal antara guru dengan siswa, antara siswa dengan siswa merupakan komunikasi multiarah yang sesuai dengan konsep siswa aktif. 
Di dalam kelas kooperatif siswa belajar bersama kelompok kecil yang terdiri dari 4-6 orang orang yang berbeda (heterogen), kemampuan, jenis kelamin, suku/ras, dn satu sama lain saling membantu (Trianto $2007: 4$ ). Tujuan dibentuknya kelompok tersebut adalah untuk memberikan kesempatan kepada semua siswa agar dapat terlibat aktif dalam proses pembelajaran berlangsung selama bekerja dengan kelompoknya. Tugas kelompok adalah mencapai ketuntasan materi yang disajikanoleh guru, saling membantu teman sekelompoknya untuk mencapai ketuntasan belajar tersebut. Keadaan dalam kebersamaan di dalam kelompok membuat siswa antusias untuk mengikuti pembelajaran, berani berpendapat dan percaya diri mengemukakan apa yang mereka ketahui. Waktu yang ada tidak hanya untuk bersantai-santai akan tetapi digunakan dengan baik seperti berdiskusi bersama temantemannya.

Peneliti mendeskripsikan bahwa Model Pembelajaran Interaktif Seting Kooperatif merupakan model yang menyenangkan bukan hanya berfikir secara individu tetapi berkelompok. Dapat meminimalisir siswa yang cepat jenuh dan bosan saat pembelajaran serta meningkatkan motivasi belajar siswa sebelum siswa diberi tugas oleh guru membaca materi sebelumnya dan mengaitkannya dengan materi yang sedang berlangsung, sehingga siswa tidak diam ketika guru bertanya, dengan begitu siswa akan mempunyai bekal pengetahuan terlebih dahulu sebelum memulai materi baru. Bukan hanya model pembelajaranya saja yang menyenangkan, guru pun harus bisa mengelola dan membuat senang suasana kelas seperti memberikan ice breaking disela-sela pembelajaran. Hal ini terbukti pada pelaksanaan tindakan yang meliputi siklus I, II, dan III yaitu :

a. Implementasi model Pembelajaran Interaktif Seting Kooperatif di atas menunjukan adanya peningkatan yaitu pada siklus I mengalami peningkatan dari 62,5\% dengan kategori aktif menjadi 92,5\% di siklus II dengan kategori sangat aktif, kemudian di siklus III menjadi 95\% dengan kategori sangat aktif hanya peningkatan persentasenya saja yang membedakan dari setiap siklusnya. Adanya peningkatan sebesar 30\% dari 
siklus I ke siklus II dan mengalami peningkatan sebesar 20\% dari siklus II ke siklus III.

b. Adanya peningkatan motivasi dan hasil belajar siswa dari setiap siklusnya. Dari lembar pengamatan motivasi belajar siswa pada siklus I mengalami peningkatan dari 57,5\% dengan kategori aktif menjadi 90\% dengan kategori sangat aktif di siklus II, kemudian di siklus III menjadi 97,5\% dengan kategori sangat aktif hanya saja yang membedakannya persentase antara siklus II dan III. Adanya peningkatan dari siklus I ke siklus II sebesar 32,5\% dan peningkatan sebesar 7,5\% dari siklus II ke siklus III.

c. Hasil belajar siswa yaitu dari rata-rata kelas pra siklus 58,03 kemudian meningkat pada siklus I menjadi 67 siklus II menjadi 74 dan siklus III menjadi 80 sehingga melampaui Kriteria Ketuntasan Minimum yaittu 75,00. Adapun peningkatan dari pra siklus ke siklus I sebesar 8,97\%, siklus I ke siklus II sebesar 7\%, dan peningkatan siklus II ke siklus III sebesar 6\%. Ketuntasan belajar pada pra siklus sebesar $14,28 \%$ atau hanya 4 siswa yang tuntas dalam hasil belajar, setelah dilaksanakan tindakakan siklus I ketuntasan belajar siswa mengalami peningkatan menjadi 12 siswa atau 50\% kemudian pada siklus II meningkat menjadi 65\% atau 18 siswa yang tuntas dalam hasil belajar dan pada siklus III mengalami peningkatan kembali sebesar 85\% atau 24 siswa yang tuntas dalam belajar. Dari hasil tersebut dapat diketahui bahwasannya ketuntasan belajar siswa telah melampaui indikator keberhasilan yang telah ditetapkan yaitu sebesar 75\% dari jumlah keseluruhan siswa. Adapun peningkatan yang dicapai dari pra siklus ke siklus I sebesar 36\%, siklus I ke siklus II sebesar 15\%, dan peningkatan dari siklus II ke siklus III sebesar $20 \%$.

Hal tersebut tidak bisa dipungkiri bahwasanya menurut observer dan guru mata pelajaran IPS implementasi model Pembelajaran Interaktif Seting Kooperatif dapat meningkatkan motivasi dan hasil belajar siswa, terlihat saat pembelajaran berlangsung siswa antusias dan semangat mengikuti pembelajaran, aktif dalam mengemukakan pendapatnya di depan teman-temannya dan percaya diri. Dan diperkuat juga oleh pendapat siswa ketika diwawancarai. Bahwasannya mereka sangat menyukai 
diterapkannya model pembelajaran interaktif seting kooperatif kerena bisa membantu mereka dalam kesulitan belajar apabila dalam kegiatan proses pembelajaran di kelas belum seluruhnya mengerti. Mereka juga sangat termotivasi dan aktif apabila dalam pelaksanaan pembelajaran IPS menggunakan model pembelajaran interaktif seting kooperatif, karena dimana setiap kelompoknya berusaha untuk memahami materi yang diberikan dan terjadi interaksi antar anggota kelompok maupun dengan guru dan saling membantu.

\section{E. KESIMPULAN DAN SARAN}

\section{Kesimpulan}

Berdasarkan hasil penelitian dan pembahasan maka dapat disimpulkan bahwa:

a. Implementasi model Pembelajaran Interaktif Seting Kooperatif pada mata pelajaran IPS kelas VIII H di SMP Negeri Palimanan Kabupaten Cirebon di atas menunjukan adanya peningkatan yaitu pada siklus I mengalami peningkatan dari 62,5\% dengan kategori aktif menjadi 92,5\% di siklus II dengan kategori sangat aktif, kemudian di siklus III menjadi 95\% dengan kategori sangat aktif hanya peningkatan persentasenya saja yang membedakan dari setiap siklusnya. Adanya peningkatan sebesar 30\% dari siklus I ke siklus II dan mengalami peningkatan sebesar 20\% dari siklus II ke siklus III.

b. Motivasi belajar siswa pada mata pelajaran IPS kelas VIII H di SMP Negeri 3 Palimanan Kabupaten Cirebon saat mengimplementasikan model Pembelajaran Interaktif Seting Kooperatif mengalami peningkatan yang sangat aktif. Peningkatan tersebut dapat dilihat dari lembar observasi pengamatan motivasi belajar siswa pada siklus I, II, dan III. Pada siklus I memperoleh persentase 57,5\% dengan kategori aktif, kemudian pada siklus II memperoleh 90\% dengan kategori sangat aktif, dan pada siklus III memperoleh persentase 97,5\% dengan kategori sangat aktif hanya saja yang membedakannya persentase antara siklus II dan III. Adanya peningkatan dari siklus I ke siklus II sebesar 32,5\% dan peningkatan sebesar 7,5\% dari siklus II ke siklus III. 
c. Hasil belajar siswa pada mata pelajaran IPS kelas VIII H di SMP Negeri 3 Palimanan Kabupaten Cirebon saat mengimplementasikan model Pembelajaran Interaktif Seting Kooperatif mengalami peningkatan yang sangat efektif. Hasil tersebut dapat diketahui dari tes yang diberikan oleh guru disetiap akhir pembelajaran atau setiap siklus. Hasil belajar tersebut dapat dilihat dari siklus I, II, dan III. Sebelum mengimplementasikan model Pembelajaran Interaktif Seting Kooperatif atau pra siklus diperoleh nilai dari rata-rata kelas pra siklus 58,03 kemudian meningkat setelah mengimpementasikan model Pembelajaran Interaktif Seting Kooperatif pada siklus I menjadi 67, siklus II menjadi 74 dan siklus III menjadi 80 sehingga melampaui Kriteria Ketuntasan Minimum yaittu 75,00. Adapun peningkatan setelah dilaksanakan dari pra siklus ke siklus I sebesar 8,97\%, siklus I ke siklus II sebesar 7\%, dan peningkatan siklus II ke siklus III sebesar 6\%. Ketuntasan belajar pada pra siklus sebesar 14,28\% atau hanya 4 siswa yang tuntas dalam hasil belajar, setelah dilaksanakan tindakakan siklus I ketuntasan belajar siswa mengalami peningkatan menjadi 12 siswa atau 50\% kemudian pada siklus II meningkat menjadi 65\% atau 18 siswa yang tuntas dalam hasil belajar dan pada siklus III mengalami peningkatan kembali sebesar 85\% atau 24 siswa yang tuntas dalam belajar. Dari hasil tersebut dapat diketahui bahwasannya ketuntasan belajar siswa telah melampaui indikator keberhasilan yang telah ditetapkan yaitu sebesar $75 \%$ dari jumlah keseluruhan siswa. Adapun peningkatan yang dicapai dari pra siklus ke siklus I sebesar 36\%, siklus I ke siklus II sebesar 15\%, dan peningkatan dari siklus II ke siklus III sebesar $20 \%$.

\section{Saran}

Berdasarkan hasil penelitian dan pembahasan maka saran yang diberikan sebagai berikut :

a. Model pembelajaran interaktif seting kooperatif terbukti dapat meningkatkan motivasi dan hasil belajar siswa. Diharapkan guru mampu mendesain model pembelajaran ini dengan efisien dan efektif sehingga mampu memanfaatkan waktu yang tersedia selain itu guru 
diharapkan dapat memiliki keterampilan dalam mengelola pembelajaran dikelas.

b. Guru diharapkan memberikan motivasi dan remedial untuk hasil belajar yang belum maksimal agar siswa tetap semangat dalam belajar.

\section{DAFTAR PUSTAKA}

Arikunto, Suharsimi. 2015. Penelitian Tindakan Kelas. Jakarta: Bumi Aksara.

Aryani, Susanti. 2010. Pendidikan Kewarganegaraan Berbasis Nilai. Bogor: Ghalia Indonesia.

Djamarah, Dkk. 2005. Strategi Belajar Mengajar. Jakarta: Rineka Cipta.

Kunandar, Abdul. 2013. Langkah Muda Penelitian Tindakan Kelas. Depok: Raja Grafindo Persada.

Purwanto,Ngalim. 2007. Psikologi Pendidikan. Bandung : Remaja Rosdakarya.

Rusman. 2011. Model-Model Mengembangkan Profesionalisme Guru. Jakarta: Raja Grafindo: Persada.

Ratunaman, T.G.2003. Pengembangan Model Pembelajaran Interaktif Seting Kooperatif (PISK) dan Pengaruhnya Terhadap Hasil Belajar Matematika Siswa SLTP di kota Ambon. Universitas Negeri Surabaya

Slameto. 2003. Belajar Dan Faktor-Faktor Yang Mempengaruhinya. Jakarta: RinekaCipta.

Somadoyo, Samsu. 2013. Penelitian Tindakan Kelas. Yogyakarta: Graha Ilmu.

Subur. 2015. Pembelajaran Nilai Moral Berbasis Kisah. Yogyakarta: Kalimedia.

Sudjana, Nana. 2016. Penilaian Hasil Proses Belajar Mengajar. Bandung: Remaja Rosdakarya.

Syah, Muhibbin. 2010. Psikologi Pendidikan Dengan Pendekatan Baru. Bandung: Remaja Rosdakarya. 